fully adapted apparatus must have originated in an organ performing some comparatively simple function. The question at issue may perhaps be stated as follows:--In the cases where the nectar-glands are now well developed has there been a special course of structural development in close relation with the need of the plant for protection? Has there heen a course of evolution such as we may believe has taken place in the formation of the food-bodies in Acacia spharecepplata and Cecropia peltata, or should we not rather believe that the sweet secretion has been developed in connection with some unknown process of nutrition ; according to this view, a well developed system of glands may continue merely performing some obscure excretory function, and conseguently, although the presence of nectar-glands has undoubtedly been of the utmost importance in determining the survival of certain species, yet it is hardly fair to assume that all nectar glands were originally protective in function. For many plants secrete large quantities of sweet fluid, which serves no such purpose. This argument is given by my father in his "Effects of Cross and Self-Fertilisation" (p. 402). In addition to the facts there given in support of this view, a curious cace described by Prof. H. Hoffmann may be mentioned ("Ueber Honigthau," I876). He states that numerous large drops of sweetish fluid appeared on the under-surface of the young leaves of a camellia. He also alludes to a similar abnormal production of honey-dew on an ivy plant.

In the case of introduced plants, we see how an already existingr quality may, without any special course of development, become of vital importance to its possessor. Thus, Mr. Belt shows ("Naturalist in Nicaragua," p. 74) that the lime, Citrus limonum, is able to exist in a wild state, because its leaves are, from some unknown reason, distasteful to the leaf-cutting ants; whereas the orange, $C$. aurantium, and the citron, $C$. medica, can only survive with the help of man.

Frity Muiller concludes his letter with some curious facts on kindred subjects :-

"The extreme variability of the nectar-glands on the leaves of many plants, is a somewhat remarkable fact. Thus our Citharexylon bas normally two large glands at the base of the leaves, but sometimes there is only one, and sometimes none at all; besides these there are small glands scattered over the surface of the leaf, the number of which varies from twenty to none. Similar variations occur in the nectar-glands of Alchornea er)'tirostermum, and of a Xanthoxylon. It seems to me probable that in all the cases at present known, these glands serve to attract protecting ants; and I here agree with Delpino, although $I$ do not hold with him that caterpillars are the chief enemies which are guarded against by Pheidole and Crematogaster; but $\mathrm{I}$ think with Belt that these latter ants protect the plant against the leaf-cutting species. Indeed it is precisely those plants which are free from the attacks of ants that seem to be especially well fitted for caterpillars. Thus the larvæ of Gynacria live on Cecropia peltata, those of Epicalia numilia on Alchornea erythrospermum. On the Cayien (?) whose leaves are furnished with nectar-glands, and are visited by protecting ants, the caterpillars of many species of Callidryas are found. Finally, as far as I know, all the larvæ of the genus Heliconius feed on Passiflora. Moreover, the same relation holds in the case of plants protected in other ways, for instance, by stinging hairs or by poisonous sap. How numerous are the larvæ found on the European stinging-nettle. In this country we find the caterpillars of 'Ageronien' on the stinging Dalechampia; and again those of some species of Danais on Asclepias, which is protected by its milky juice."

Down, Beckenham, May $2 \mathbf{I}$

\section{Quartzite Implements at Brandon}

At the recent conference held by the Anthropological Society on the present state of the question of the antiquity of man, the president, Mr. John Evans, referred to the finding of implements made of quartzite at Brandon, and remarked that as that rock did not exist in the neighbourhood excepting in the glacial drift, the implements must have been made from pebbles obtained from the glacial beds, and were therefore of post-glacial age. This statement was made at the end of the meeting when there was no opportunity of replying to it, and as its effect must have been great, I shall be obiiged if you will allow one who believes that none of the palæolithic implements are of postglacial manufacture to make some remarks upon it.

For a full description of the implement-bearing deposits near
Brandon I must refer to an able paper by Mr. J. W. Flower in the twenty-fifth volume of the Quarterly Fournal of the Geological Society. Gravel Hill, near Brandon, is an isolated hill rising to a height of $9 \mathrm{I}$ feet above the river, from which it is nearly a mile distant. It is covered with gravel which is mostly, and in some places entirely, composed of quartzite pebbles. Mr. Flower estimates that three-fourths of the whole are of quartzite. In this the gravel differs from that of other pits in the neighbourhood of Brandon, as for instance, that at Brombill, which contains only one thirtieth part of quartzose pebbles.

At Gravel Hill, along with some hundreds of fint implements, four made of quartzite, similar to that of the pebbles, have been found. All the implements are usually found at the bottom of the gravel, and occasionally lie on the chalk. On the supposition that the quartzose pebbles, from which some of the implements have been made, were brought by ice in the glacial period, some such succession of events as the following must have occurred. I. Ice, from the north, carried thousands of quartzite stones and deposited them in immense abundance over a limited area. 2. Man afterwards made implements from some of them. 3. The whole of the pebbles were rearranged and formed into beds of gravel with the implements at the bottom, whilst the distinclive character of the deposit was retained.

This ingenious but complicated theory is not necessary, for guartzose boulders and pebbles are found in deposits much older than the glacial period not very far away from the locality, and may exist beneath the drift close to it. It has long been known to geologists that there are many fragments of old crystalline rock in the upper greensand. They have been described by $\mathrm{Mr}$. Bonney in his geology of Cambridge, and very fully by Messrs. Sollas and JukesBrowne, who state that fragments of gneiss, mica, and hornblende schists, talcose schists, granites, vein quart $z$, grits, quartzites, and slates are very numerous in this bed. It ranges northward from Cambridge, and is lost beneath the surface gravels and boulder clays, but it is not at all improbable that it may run along to the west of Brandon, and there contain even more quartzose fragments than in Cambridgeshire.

I may remark in conciusion that $\mathrm{Mr}$. Flower, in his description, states, that he is disposed with the French geologis!s, to ascribe the outspread of the gravels to some powerful cataclysmal action, and that he does not know of any bouider clays in the course of the river from which such a mass of pebbles could have been derived.

Cornwall House, Ealing

\section{The Migration of the Swiss Miocene Flora}

WITH reference to the route the plants took which formed the European miocene flora, I should be glad to know whry Dr. Unver considers it to have been from America to Europe. $\mathrm{He}$ says: "There is more than one reason for thinking that the centre from which our lignite flora has sprung was far away, from Europe -in the southern parts of the United States" (Fourn. of Bot., iii. 17). He thinks that the living flora of that part of America is the lineal descendant of that which gave rise, by aid of "Atlantis," to the Swiss miocene flora. But is enough known of the miocene flora of the United States to infer this? Prof. Heer says that the methods of comparison he employed "incontestably prove that Switzerland was inhabited by types now scattered over every part of the world [agreeing in that respect with the existing Arctic flora], but of which the majority correspond with species of South U.S. of America; the Mediterranean region of Europe ranks second ; Asia Minor, the Caucasus, and Japan third; the Atlantic Isles fourth, and North Holland fifth" (Nat. Hist. Rev., 1862, p. 154, quoted by Oliver). Prof. Oliver and Sir Charles Lyell think that the route was by Japan, and not by the Atlantis; but still (Sir Charles, ar least) from America to Europe. Heer, in his "Primæval World of Switzerland" (vol. i. p. 325, Eng. ed.), says the Glyptostrobus heterophyllus of Japan "has probably been derived from the tertiary species" [of Europe]. Similarly, in comparing the Taxodium distichum miocenum with that of America, he observes: "It is very interesting to find that the ancestors of the existing American swamp-cypresses were formerly spread over the whole of Europe, as far as $78^{\circ}$ N. lat. Again, of Sequoia Langsdorfii, he observes: "It probably formed a zone round the whole earth in high northern latitudes."

Instead, then, of regarding either Switzerland or the South U.S. as a "centre," I would suggest that the miocene flora was uniformly spread over the whole of the regions bordering the 